> Gi respons på artikler gjennom artiklenes kommentarfelt på tidsskriftet.no.

Innleggene publiseres fortløpende på Tidsskriftets nettside og et utvalg

av innleggene publiseres også i papirutgaven i spalten «Brev til redaktøren».

Redaksjonen forbeholder seg retten til å foreta redaksjonelle endringer.

Forfattere av vitenskapelige artikler har tilsvarsrett, jf. Vancouver-gruppens regler.

\section{Re: Barnet på det innvandringspolitiske alter?}

I Tidsskriftet 5/2016 (1) og i oppslag i Vårt Land (2) og Aftenposten (3) rettes søkelyset mot kirurgisk behandling av et barn født i Norge med analatresi. Foreldrene hadde søkt om asyl før barnet ble født, og barnet hadde en uforutsett og behandlingskrevende tilstand. Planlagt korrigerende behandling ble avlyst av Oslo universitetssykehus med begrunnelse om usikker asylstatus. Saken reiser flere problemstillinger omkring behandlende legers rolle som forvaltere av kunnskap og ressurser. Denne typen analatresi behandles vanligvis med en avlastende lav colostomi, etterfulgt av PSARP (posterior sagittal anorektoplastikk) omkring to måneders alder og tilbakelegging av stomi når analkanalen har tilhelet og fått riktig dimensjon etter blokking. I dette tilfellet begrunnes avvik fra etablert behandling med at kolostomi i utgangspunkt like godt kan være en permanent løsning for barn med denne typen misdannelser (1).

Mon det. Permanent kolostomi blir ansett som utilstrekkelig for nyfødte født i den industrialiserte del av verden, og er ikke et alternativ for barn med norsk pass. Kolostomi omtales ikke i standard referanselitteratur hos barn med normal nevrologi, annet enn som en midlertidig løsning. Tilgjengelig stomiutstyr samt tilsyn fra kompetent personell er nødvendig for at kolostomi skal fungere - også midlertidig. En familie på flukt med et spedbarn er ikke sikret en slik oppfølging. Fullført rekonstruktiv kirurgi forventes å gi et annet forløp.

I rundskriv fra Helse- og omsorgsdepartementet (nr. 1-5/2011) (4) framgår det klart at asylsøkende barn har «...fulle rettigheter til helsehjelp, med mindre hensynet til barnet selv tilsier at helsehjelp ikke skal ytes». Barnet var fire måneder da asylsøknad ble avslått, og seks måneder da familien ble uttransportert. Med et normalt tidsforløp er det grunn til å tro at hele behandlingen ville blitt gjennomført i Norge.

Utlendingsnemnda lener seg tungt på den medisinskfaglige vurderingen når asylsøknaden blir avslått, mens behandlende avdeling langt på vei begrunner avlyst behandling med mulig framtidig avslag på asylsøknad. Slik havner ansvaret $\mathrm{i}$ et tomrom mellom medisin og innvandringspolitikk, der barnet blir den skadelidende part.

Barnelegeforeningen mener denne saken illustrerer at vi som leger kan bli faglige alibi for politiske hensyn. Barnets beste skal alltid ha førsteprioritet for medisinsk personell; derfor bør våre medisinske anbefalinger ikke avvike fra den behandling vi ville gitt til andre barn født i Norge. Det er opp til politiske myndigheter om andre hensyn skal veie tyngre. Vi synes det er betenkelig å holde tilbake standard behandling i påvente av et mulig avslag på asyl.

Barnet fikk sin endelige operasjon på flukt etter et forutsigbart avslag i Ungarn - tyske kolleger kunne gi behandling som Norge ikke ville tilby. Dette er en sak å trekke lærdom av, og vi håper at behandlende avdeling tar selvkritikk. Sammen med barneombudet og myndigheter vil vi arbeide for å få klarere retningslinjer for medisinske erklæringer i asylsaker.

\section{Ketil Størdal \\ ketil.stordal@gmail.com \\ Ingebjørg Fagerli}

Ketil Størdal (f. 1966) er overlege ved Sykehuset $\emptyset$ stfold og nestleder i Norsk Barnelegeforening

Ingen oppgitte interessekonflikter.
Ingebjørg Fagerli (f. 1958) leder i Norsk Barnelegeforening

Ingen oppgitte interessekonflikter.

Litteratur

1. Alnæs-Katjavivi P, Lie M. Barnet på det innvandringspolitiske alter? Tidsskr Nor Legeforen 2016; 136: 387-8.

2. Sylte T. - Baby måtte flykte med utlagt tarm. Vårt Land 15.2.2015.

3. Aftenposten - En gutt ble født med alvorlig misdannelse. Likevel ble han sendt ut av landet. Aftenposten 9.3.2016.

4. Helse- og omsorgsdepartementet. Helsehjelp til personer uten fast opphold i riket og personer uten lovlig opphold. Rundskriv. www.regjeringen.no/ globalassets/upload/hod/hra/i5-2011.pdf (1.4.2016).

\section{Re: Bruk av skjema i oppfølgingen av diabetes i allmennpraksis}

Etter en henvendelse fra Norsk forening for allmennmedisin har Kunnskapssenteret i Tidsskriftet nr. 5/2016 publisert en systematisk oversikt av effekten av bruk av skjema i oppfølging av diabetes i allmennpraksis (1). Vi er enige i forfatternes fortolkning av studien; det er tendens til at bruk av diabetesskjema kan bidra til lavere dødelighet og sykelighet. Den vitenskapelige evidensen for dette er lav. Seks av de syv inkluderte studiene var av så kort varighet at man ikke kan forvente noen effekt på hjerte- og karsykdom eller dødelighet. Den lengste studien viste imidlertid tendens til en gunstig effekt. Ingen av studiene undersøkte effekt på prosessindikatorer eller andel som var dårlig regulert, og bare fire ga tilbakemelding til legene. Forfatterne refererer til at andre systematiske undersøkelser har vist at databaserte systemer for klinisk beslutningsstøtte kan medføre praksisendring og helsegevinst. På populasjonsnivå er en gjennomsnittlig reduksjon i systolisk blodtrykk på $3 \mathrm{~mm} \mathrm{Hg}$ betydelig. Mange deltakere og lang observasjonstid må til for å påvise en reduksjon i komplikasjoner og død.

«Noklus diabetesskjema» er et beslutningsstøtteprogram og en registreringsmodul for «Norsk diabetesregister for voksne (NDRV)». Innrapportering av data til registeret gir årlig tilbakemelding til fastlegen om kvaliteten på diabetesbehandlingen i praksisen. Data fra registeret kan gi viktig informasjon om status for diabetesoppfølging og behandling i Norge. Lokale rapporter gir fastlegen mulighet til ekstra oppfølging av pasientene med dårlig kontroll. Så vidt vi forstår skiller dette seg vesentlig fra de systemene som er benyttet i de inkluderte studiene. Disse studiene er derfor lite representative for å vurdere effekten av «Noklus diabetesskjema».

Data fra norsk allmennpraksis viser et stort forbedringspotensial for oppfølging og behandling av diabetes. Undersøkelse av føtter, U-albumin og øyelege som anbefalt i de kliniske retningslinjer var kun dokumentert hos $25-70 \%$ (2). For allmennpraktikere kan hjelpemidler som «Noklus diabeteskjema» fungere som viktig påminnelse, huskeliste og arbeidsverktøy som også kan bidra til redusert tidsbruk. Vårt inntrykk, som bekreftes ved upubliserte undersøkelser fra allmennpraksis i Salten og sykehusdata fra «NDRV», tyder på at bruk av strukturerte diabetesskjema/journaler fører til en bedring av kvaliteten på behandlingen. Vi er imidlertid enige med forfatterne at det er få gode undersøkelser om effekten av bruk av skjema, og at det er ønskelig med studier som kan avklare dette nærmere. Den pågående ROSA-4 undersøkelsen som inkluderer diabetespasienter fra allmennpraksis vil gi nyere data om dette. 
Det er vanskelig å bli bedre hvis man ikke vet hva man gjør. Vi oppfordrer allmennleger til fortsatt bruk av «Noklus diabetesskjema» både for å få systematikk i diabeteskontrollene og for å levere data til diabetesregisteret.

\section{John Graham Cooper \\ joco@sus.no \\ Tor Claudi \\ Kristian Jong Høines \\ Inger Lyngstad \\ Bjørn Gjelsvik \\ Gunnar Mouland \\ Normund Svoen \\ Anne Karen Jenum}

John Graham Cooper (f. 1950) er medisinsk ansvarlig lege, Norsk diabetesregister for voksne, Stavanger universitetssjukehus/Noklus Ingen andre oppgitte interessekonflikter.

Tor Claudi (f. 1947) er overlege ved medisinsk klinikk, Nordlandssykehuset Bodø.

Ingen oppgitte interessekonflikter.

Kristian Jong Høines (f. 1975) er fastlege ved Tananger Legesenter. Ingen oppgitte interessekonflikter.

Inger Lyngstad (f. 1957) er fastlege ved Ringerike Medisinske Senter, Hønefoss.

Ingen oppgitte interessekonflikter

Bjørn Gjelsvik (f. 1949) er førsteamanuensis ved avdeling for allmennmedisin, Universitetet i Oslo og fastlege ved Tanum Legekontor, Slependen.

Ingen oppgitte interessekonflikter.

Gunnar Mouland (f. 1948) er fastlege ved Legegruppen Arendal. Ingen oppgitte interessekonflikter.

Normund Svoen (f. 1956) er fastlege ved Legegruppa Sunnfjord Medisinske Senter, Florø

Ingen oppgitte interessekonflikter.

Anne Karen Jenum (f. 1951) er professor ved Universitetet i Oslo, Medisinsk fakultet, Institutt for helse og samfunn, Avdeling for allmennmedisin.

Ingen oppgitte interessekonflikter.

Litteratur

1. Larun L, Bjørner T. Fretheim A et al. Bruk av skjema i oppfølgingen av diabetes i allmennpraksis. Tidsskr Nor Legeforen 2016; 136: 417-22.

2. Claudi T, Ingskog W, Cooper JG et al. Kvaliteten på diabetesbehandlingen i allmennpraksis. Tidsskr Nor Legeforen 2008; 128: 2570-4.

\section{Re: Risikojustering ved måling av predikert dødelighet etter hjerteinfarkt}

Vi har med interesse lest Hagen og medarbeideres artikkel der de viser hvorledes risikojusterte verdier for 30 dagers mortalitet etter hjerteinfarkt endres avhengig av hvilke variabler som inngår i regresjonsmodellen for risikojustering (1). Best samsvar mellom predikert og faktisk mortalitet forelå der man justerte for alder, kjønn, grad av sykdom (hjerteinfarkt), komorbiditet, reisetid og PCI innen 14 dager.

Studien illustrerer utstrakt bruk av registerdata og er både forbilledlig og betimelig all den tid våre helsemyndigheter allerede er i gang med å fordele deler av helseforetakenes finansiering basert på kvalitetsindikatorer (kvalitetsbasert finansiering - KBF). 30 dagers mortalitet etter hjerteinfarkt er en av en rekke målte kvalitetsindikatorer som her inngår med uklar risikojustering.
Det er ikke første gang det etterlyses en troverdig risikojustering av kvalitetsdata av typen behandlingsresultater som publiseres på Helsedirektoratets hjemmesider (helsenorge.no) og som nå ligger til grunn for kvalitetsbasert finansiering. Vi har tidligere påpekt at dersom man skal sammenligne kvalitetsmål av typen behandlingsresultater, så må adekvate og kontinuerlig oppdaterte modeller for risikojustering være på plass (2).

30 dagers mortalitet etter hjerteinfarkt er 1 av 10 kvalitetsindikatorer av type behandlingsresultater som inngår i KBF. Her har man etter vår mening en stor jobb å gjøre med å etablere gode modeller for risikojustering etter mønster av Hagen og medforfattere.

Ved siden av uklar risikojustering deler vi artikkelforfatternes bekymring for at kvalitetsbasert finansiering kan lede til uheldige tilpasninger i form av seleksjon og overbehandling av pasientgrupper. Kodeverket (ICD) åpner også for en viss grad av skjønn når alvorlighet av sykdom skal beskrives. Vi har tidligere sett eksempler på uheldig bruk av diagnoseverktøyet når det får økonomiske konsekvenser.

Et poeng som også nevnes er at kvalitetmåls nærhet i tid og sted er viktig for at det skal oppleves som meningsfullt for dem som bidrar. Det kan være en viss fare for at belønningssystemer basert på 30 ulike indikatormål på overordnet foretaksnivå vil drukne den enkeltes innsats og på den måten ikke gi den stimuleringseffekten man er ute etter.

Etter vår mening har artikkelforfatterne pekt på en rekke forhold som det er avgjørende at våre helsemyndigheter tar inn over seg i den bebudede evalueringen av forsøket med kvalitetsbasert finansiering.

Marius Asplin

marius.asplin@gmail.no

Even Fagermoen

Marius Asplin (f. 1960) er overlege ved Akuttklinikken, Oslo universitetssykehus.

Ingen oppgitte interessekonflikter.

Even Fagermoen (f.1967) er overlege Akuttklinikken, Oslo universitetssykehus.

Ingen oppgitte interessekonflikter.

\section{Litteratur}

1. Hagen TP, Iversen T, Moger TA. Risikojustering ved måling av predikert dødelighet etter hjerteinfarkt. Tidsskr Nor Legeforen 2016: 136: 423-7.

2. Asplin M, Fagermoen E. Hvordan sammenlikner vi kvalitet i helsetjenesten? Tidsskr Nor Legeforen 2015; 135: 1112-3.

\section{Re: Risikojustering ved måling av predikert dødelighet etter hjerteinfarkt}

Artikkelen til Hagen og medarbeidere i Tidsskriftet nr. 5/2016 (1) tar opp et viktig tema: hvordan kan vi bruke harde utfallsmål til å vurdere kvalitet i helsetjenesten. Vi tror det er nyttig at temaet blir behandlet $\mathrm{i}$ et norsk faglig forum. Forfatterne diskuterer hvordan man kan justere utfallsmål for forskjeller i pasientsammensetning. I innledningen viser de til at kvalitetsindikatoren 30-dagersoverlevelse etter innleggelse ved sykehus inngår i grunnlaget for kvalitetsbasert finansiering, og skriver at «... det ikke er gjort rede for hvordan overlevelsestallene er risikojustert». Her må vi påpeke at denne indikatoren er meget godt beskrevet i vitenskapelige publikasjoner $(2,3)$ og i en rekke rapporter (4-7) fra Kunnskapssenteret, som nå er en del av Folkehelseinstituttet.

Vi vil også peke på en viktig prinsipiell side ved risikojustering: den må bare justere for forhold som foreligger ved innleggelsesøyeblikket. Det er helt feil å justere for behandling, f.eks. om pasienten får PCI eller ikke, som Hagen og medarbeidere beskriver. Det er jo nettopp forskjeller i behandling som kan forårsake forskjeller i utfall. Ellers er det mange likhetstrekk mellom metoden i artik- 